\title{
Board ethos and institutional work: Developing a corporate governance identity through developing the UK code
}

\author{
Donald Nordberg ${ }^{1}$ \\ (accepted for publication in Business and Economics Review, 2017)
}

\begin{abstract}
Codes of conduct seek to institutionalize certain practices and govern the actions of those who accept the regime. As they arise and seek to displace established ways of life in organizations, they provide examples institutional development and change. This paper examines how the UK code of corporate governance arose and developed over time, and how it leads to a common understanding across various fields of social actors. Specifically, it examines the debate about what the ethos of the board for directors should be, as exhibited in consultations informing the 1992, 2003 and 2010 versions of the code. It shows social actors, as expected, taking stances aligned with their economic interests. But over time and through the institutional work involved in the debate, some of those actors identify increasingly with the process, and the collective understanding informs the identity of those participants.
\end{abstract}

Keywords: Codes of conduct, corporate governance, institutional work, identity, UK

\section{Introduction}

In corporate governance, and in many countries around the world, codes have become the mechanism through which boards and to some extent investors have organized their work. Companies, investors, regulators and states alike have come to the view that the internal direction-setting and control of corporations is too complex and particular to be the subject of detailed legislation or regulation. But corporate misdemeanours and malfeasance have been too prevalent and costly to leave to individual decision-making. The preferred solution in many places has been to turn to binding-yet-voluntary codes.

\footnotetext{
${ }^{1}$ Donald Nordberg is Associate Professor of Strategy and Corporate Governance at Bournemouth University Business School. His work has been published in journals including Corporate Governance: An International Review, Business History, Business Ethics: A European Review, Review of Political Economy. His book, Corporate Governance: Principles and Issues, was published by Sage in 2011.
} 
Codes of conduct exist within companies and industries and across countries and multilateral organizations, with increasingly widespread use (Paine, Deshpandé, Margolis, \& Bettcher, 2005; Seidl, 2007). They guide the actions of individuals and organizations without the force or the inflexibility of law but also without political cost (O'Rourke, 2003). They seek followers through demonstrating the legitimacy of their recommendations, and gain legitimacy by the followers they collect. Codes have institutional characteristics, but they are not automatically institutions.

This paper explores the processes through which one such proto-institution (Lawrence, Hardy, \& Phillips, 2002; Zietsma \& McKnight, 2009), the UK code of corporate governance, gains adherents and confers legitimacy on those who adopt it through the institutional work (Lawrence \& Suddaby, 2006) involved in its development. Starting with the Cadbury Code in 1992 and the continuing revisions to the current UK Corporate Governance Code of 2016, corporate governance practices have become institutionalized.

Moreover, the UK code has served as a model for code development in other countries, including France and Germany, Russia and Japan. It has also influenced thinking from the Organisation for Economic Co-operation and Development (OECD, 1999, 2004), and the World Bank (IFC, 2005, 2007) in developing guidelines for corporations arising in transition economies of central and eastern Europe and the developing world in Asia, Africa and Latin America (Aguilera \& Cuervo-Cazurra, 2004, 2009). However, the similarities of code around the world may somewhat uncomfortably given the varieties for formal institutions in law and regulations, that is, the varieties of capitalism practices under differing institutional settings (Hall \& Soskice, 2001).

Over the past 25 years, the content of the UK's code has shown considerable continuity, despite recurring shocks. But they have seen a shift in emphasis. The discourse of board 
effectiveness has moved from structure in Cadbury, to independence in the 2003 version, to recognition in 2010 the importance of behaviour, particularly in supportive yet challenging relationships between directors (Nordberg \& McNulty, 2013). In so doing, it has reflected the tenuous links between either code-based governance structures and metrics of independence on the one hand and performance on the other (Love, 2011). Moreover, it resonates with growing interest in the concept of behavioural governance (Marnet, 2007; van Ees, Gabrielsson, \& Huse, 2009; Vandewaerde, Voordeckers, Lambrechts, \& Bammens, 2011).

In the formulation and evolution of the code, what processes - involving which actors, arguments and actions - allowed this code to become institutionalized and then led to this change of discourse? The consultations considered issues of board design and composition, tenure of directors, board evaluation processes, and the nature of enforcement and compliance, but one question linked several of the debates: What is the right ethos for the boardroom? Ethos goes to the heart of the question of behaviour.

This paper considers briefly the literature on board effectiveness and the steps taken in writing the first code in 1992 and in the major revisions of 2003 and 2010. Next it outlines institutional theory, institutional work and identity work in particular. Following a comment on methodology, the paper examines the contributions to the debate of boardroom ethos and behaviour from 1992 to 2010 to assess the actors from different fields, their field-based interests and identities, and nature of work they undertook. It concludes by observing in the data a complex interaction of institutional work, through which participants take on an emergent identity associated with corporate governance and the processes of codification. In so doing it contributes to our understanding of the development of the UK code and codes in other countries 
that use it as their benchmark. It also shows how the process of identification through institutional work can facilitate institutionalization in a contested field.

\section{Board effectiveness}

A central aim of the code in all its versions is to enhance board effectiveness, often described as involving opposing functions of service and control (Aguilera, 2005; Barroso, Villegas, \& Pérez-Calero, 2011; Kim, Burns, \& Prescott, 2009). The code seeks to do so through recommendations about board structure (e.g. separating the role of chairman and CEO; specifying the number of independent directors), norms (e.g. defining independence; prescribing financial expertise on audit committees) and processes (e.g. mandating disclosure; enforcing compliance).

Codes add a structural component to the processes of board effectiveness identified by Forbes and Milliken (1999), with its elements of board member characteristics that interact with effort norms and the use of knowledge and skills and operate through cognitive conflict. But the code recognizes, and with particular emphasis in 2010 and its deliberate change in tone (FRC, 2010, Preface, Paragraph 6), a more elusive quality related to how directors act towards each other and with respect to shareholders. This emphasis reflects the need for cohesiveness in a board, which Forbes and Milliken (1999) see in a tense relationship with cognitive conflict. Roberts, McNulty and Stiles (2005, p. S6) endorse a similar need in suggesting outside directors be "engaged but non-executive", "challenging but supportive" and "independent but involved".

\section{Code development}

The three main versions of the code arose in similar circumstances: Corporate failures provided a precipitating jolt (Greenwood, Suddaby, \& Hinings, 2002) that placed the legitimacy 
of current arrangements in doubt. While the jolts had similarities, the processes of codification differed in detail.

\section{Process in 1991-92}

The Cadbury Code emerged after 18 months of discussion and debate. The Financial Reporting Council and the London Stock Exchange asked Sir Adrian Cadbury, scion of a Quaker family of industrialists, to lead an inquiry starting in May 1991. Both organizations were, at the time, industry self-regulatory bodies overseeing the accounting and audit professions (FRC) and the equity markets (LSE and its UK Listing Authority); the initiative was largely a private-sector affair.

Although a private-sector initiative, the work had public backing. With support of staff seconded by the Bank of England and the Department of Trade and Industry, Sir Adrian empanelled a committee drawn from industry, the financial community and the accounting profession. They interviewed dozens of people, received contributions by post and fax, and attended public meetings. In May 1992 the committee produced a draft code and discussion paper and then undertook a formal consultation before publishing the code in December 1992. Many of the documents from that inquiry are digitized and available online (Cadbury Archive, 2010), drawn from more 200 from before the draft text was issued in May 1992 and almost as many in response to the July draft.

\section{Process in 2002-03}

Government took the lead in response to the crisis at Enron and other companies in the opening years of the 2000s. It commissioned three studies on corporate governance: The Higgs Review (2003) on the effectiveness of non-executive directors, the Smith Review (2003) on 
audit, and the Tyson Report (2003) on widening the pool of directors. The centrality of Higgs to the revision of the Combined Code that July means we focus here on responses to it.

Higgs commissioned three research studies: a statistical analysis of board composition; a survey profiling more than 600 directors (MORI, 2002); and research involving in-depth interviews with 40 corporate chairmen and directors (McNulty, Roberts, \& Stiles, 2003). The review proved controversial. The FRC chairman later recalled the "media noise level and the hostility ... by company Chairmen" (Nicholson, 2008, p. 110). What the FRC, now a government-directed agency, had intended as a quick, "fatal flaws only" review received more than 180 responses (FRC, 2004). In addition, public and private gatherings discussed the implications for companies, and institutional shareholders.

\section{Process in 2009-10}

Despite the Higgs controversy, recommended practices took hold and further revisions in 2006 and 2008 made only modest changes. But the financial crisis led to the collapse of one UK bank in 2007; the near-global meltdown forced part-nationalization of two more large British banks in 2008. The consequences were two-fold: First, the government commissioned an inquiry into the corporate governance at financial institutions (Walker, 2009a, 2009b). Second and roughly in parallel, the FRC pulled forward its review of the Combined Code by one year. For the former, the investment banker Sir David Walker undertook a two-stage consultation. His draft appeared in July and the final report in November.

While Walker focused only on financial firms, the Combined Code had broader application. The FRC conducted a three-stage consultation coordinated by its chairman, Sir Christopher Hogg. First came an open consultation about what had worked well and less well in the Combined Code. The second sought views on whether the July draft of Walker's 
recommendations for financial institutions applied to the wider field of corporations. The third sought comments on a new draft text, published a week after the final Walker Review. Each phase also prompted public and private meetings.

The FRC received more than 100 written submissions to each consultation. Some individuals and groups felt that corporate governance had taken the wrong turn - in one direction or another - and wanted to steer the code towards a different goal. For others, the code had become symbolic of what they valued in corporate governance, something to be defended against those who would dilute its aims or tighten its constraints.

Contributions to consultations shared a purpose: development of a common understanding of good corporate governance. Many participants had another aim: the avoidance of legislative or regulatory action to constrain boards. The crisis that led to the Cadbury Report probably meant the change was inevitable. New institutional arrangements would supplant undefined arrangements copied informally between boards, that is, mimetic isomorphism gives way to the normative (DiMaggio \& Powell, 1983). Some participants wanted to go further, enacting binding rules and coercing compliance. These voices, as well as the actions of the authors of the code version, may be viewed as engaging in institutional work.

\section{Institutions, work and identity}

Institutions persist over time, and yet they change. This paradox of embedded agency (Holm, 1995; Seo \& Creed, 2002) has stimulated much work in institutional theory as it seeks to overcome objections that it is only a partial theory (Clegg, 2010; Kraatz, 2011). In seeking to understand how this paradox is resolved, theorists have turned to a variety of explanations. 


\section{Institutional work}

DiMaggio (1988) introduced the term institutional entrepreneurship to explain how actors use ideas from outside to dislodge incumbent practices and create opportunities for change. Oliver (1992, p. 564) argues that deinstitutionalization represents "the delegitimation of an established organizational practice or procedure" in response to challenges facing the organization of or the failure of organizations to perform as expected. Greenwood and Hinings (1996) see dissatisfaction with a changing market context and discrepancies between the values of actors and institutional arrangements as antecedents of institutional change. But what starts the process? Greenwood and colleagues (2002) theorize that a precipitating jolt from changes in the environment would make embedded actors perceive the inadequacy of current arrangements.

Greenwood and Suddaby (2006) see institutional change as coming from elites who recognize the contradictions in the institutional field and initiate change. But Rao and Giorgi (2006) contend that actors on the periphery of a social system can effect change as well. These depictions suggest that change arises from the choices initiated by actors but largely in response to environmental issues that undermine the institution's legitimacy.

Extending the entrepreneurship concept, Lawrence and Suddaby (2006, p. 215) introduce the term institutional work to encompass "purposive action of individuals or organizations aimed at creating, maintaining and disrupting institutions". Work is intentional, not simply routinized behaviour, the effort of agency rather than the product of structure. Lawrence, Suddaby and Leca (2011, p. 56) argue that concept of institutional work provides a "bridge" between critical and institutional views of organizations by focusing on actors, their intentions and hidden voices.

Institutional work depends on agency, which may vary over time. Emirbayer and Mische (1998, p. 1012) assert that actors "are always living simultaneously in the past, future, and present". They identify three types of agency: a backward-oriented approach they call iterative; 
the present-oriented, practical-evaluative type; and a forward-looking form they call projective. Battilana and D'Aunno (2009) use these categories to elaborate institutional work, setting them against categories of actions in Lawrence and Suddaby (2006) involved in creating, maintaining and disrupting institutions. Iterative agency involves repeated steps to emphasize persistence; the practical-evaluative type demonstrates the (in)efficacy of the logics they support or wish to disrupt; projective agency involves imagining a different future state. The 20 types of institutional work they articulate overlap with the 18 in Lawrence and Suddaby (2006). It also offers some new forms of work, including two they see as work involved in creating institutions in present-oriented, practical-evaluative agency. Actors interpret institutional arrangements (translation) or assemble elements from different mechanisms (bricolage) to fit particular settings. As we shall see, both have resonances in the way individual companies respond to corporate governance arrangements under a comply-or-explain regime involved internationally active actors. Moreover, translation suggests that ideas often do not diffuse intact through a field but instead are interpreted as they pass from one actor to another (Czarniawska, 2007; Czarniawska \& Joerges, 1996).

\section{Identity work in institutional theory}

Institutional work can take the form of individuals identifying with the institution or with alternative arrangements. Creed and colleagues (2010, p. 1337) describe the "identity work" of marginalized actors through a process that can be both "conservative and disruptive". This depiction suggests that institutional work need not sit firmly within the categories of "creating", “maintaining" or "disrupting" identified by Lawrence and Suddaby (2006). In a study related to the present paper, Lok (2010) found that both investors and corporate managers invoked conflicting logics, differing identities and contrasting associated practices in their approach to 
corporate governance, and suggested that these contradictions can persist over long periods. $\mathrm{He}$ notes that "self-identity can continue to be fractured and inconsistent, invoking different contradictory practices under different circumstances and at different times" (Lok, 2010, p. 1326). The intentionality of institutional work (Lawrence \& Suddaby, 2006) combined with considerations of identity suggest the nature of institutional work may be dependent on the interpretation actors give to aspects of the institution and its logic. With this background in mind we look at what institutional work happened during the consultations about UK corporate governance, following a description of the methodology used.

Bévort and Suddaby (2016) see identity work in the way accountants coped with shifting institutional logics as firms grew more managerial and a profit-corporate logic clashed with the professional, client-oriented one that had long informed accountancy training and practice. Unlike many previous studies of identity and institutional work, theirs focuses on the processes of identification of individuals, rather than organizations. The study urges scholars to pay closer attention to individuals as social actors in seeking to establish the processes of institutionalization and institutional change. The present study seeks to do that by attending to both organizational and personal contributions to the debate over the nature of corporate boards.

\section{Methodology}

To examination institutional work and identification, this paper uses evidence from the consultations that led to the creation of the UK corporate governance code in 1992, following a series of corporate governance failures. It then examines those during consultations for the major modifications undertaken as fresh crises in corporate governance struck, in the early 2000s and then in response to the financial crisis later in that decade. 
Analysis involved an iterative reading of submissions to the debates concerning the three code versions, paying close attention to language and argument. Discourse analysis developed from a more general study of themes that arise from texts into specialized disciplines using techniques drawn from fields as disparate as linguistics, literary theory, critical theory in politics and sociology and psychology (Alvesson \& Kärreman, 2000; Chia, 2000). While some studies explore these approaches in isolation to determine their methodological significance, this paper seeks to interpret texts. It requires, therefore, that we look at various aspects of language, including diction, word order, metaphor, stated and unstated allusions, as well as the use of forceful rhetoric to identify meanings and assumptions.

The documents necessarily present an incomplete view, but they provide opportunity to explore the arguments and rhetoric of officials of listed companies, financial institutions, their advisers and the general public. Formal responses may lack the spontaneity and vibrant language of face-to-face communications. Nonetheless, the submissions represent a considered distillation of views, ones that a committee or a thoughtful author would give weight to in setting policy. There is evidence of this in the data, in particular in the summaries in the Cadbury Archive, which interpret those submissions to guide committee members' thinking.

Work began by reading a large proportion of the available documents. Because of the volume of the data, detailed analysis was undertaken on a sample of papers and a subset of the issues. This study used theoretical sampling based on two criteria: First, following Greenwood and Suddaby (2006) and Rao and Giorgi (2006), was the position of actors in the field, in this case the investment supply chain. Second, was the salience of issues (Mitchell, Agle, \& Wood, 1997), which led to consideration of topics based on the controversy they aroused. 
The documents were coded in Nvivo software to categories including concepts like chairman, institutional investors, and then higher level ones like compliance, structure, independence and behaviour. As new ideas came to the fore, additional coding was applied for emerging categories, and then the papers were read again to identify axial dimensions (Strauss, 1987; Strauss \& Corbin, 1998), in this case drawing on the literature of board effectiveness. Of relevance to the analysis below, axial coding reflected the apparent tension in the data between industry expertise and independence and its effect on boardroom challenge and cohesiveness. The texts were then read against categories of institutional work developed from perspectives in Lawrence and Suddaby (2006) and Battilana and D'Aunno (2009). The data-coding presented numerous opportunities to read and re-read the source material, in their entirety and as coded.

Although the initial reading for this study ranged widely in the documentation, analysis concentrated on contributions made during public consultations: 1) after the Cadbury Committee had issued its draft in July 1992 and before the final code in December; 2) after publication of the Higgs Review in January 2003 and before the July publication of the Combined Code; and 3) all three consultation phases concerning the 2010 code.

\section{Findings}

The three versions of the code show concern about issues affecting mainly structure, independence and behaviour, with a changing emphasis over time (Nordberg \& McNulty, 2013). The consultations gathered views from a wide spectrum of actors. At the centre of the corporate governance debate were senior corporate officers, and representatives of investment firms and trade associations. At one step removed were professional advisors and importantly the accountancy profession. More peripheral actors came from public interest organizations, political actors, and those focused on non-shareholder interests. But contributors from across the spectrum 
viewed these themes as interlocking: For example, structures like board committees empower non-executive directors at the expense of executives, thus contributing to board independence and potentially influencing behaviour.

The three rounds of consultations considered issues including separation of the roles of chairman and CEO (1992 only; participants took that for granted during subsequent revisions); creating a senior independent director (1992), giving that person a specific duties with investors (2003), and then suggesting different behavioural expectations of the role (2010); the creation of committees (1992), then placed under the control of independent directors (2003); limiting the tenure of non-executives' deemed independence (2003 and 2010); frequency of director elections (all three versions); giving non-executives the right to hire external professional advice (1992 only). In both 2003 and 2010 controversy arose about whether, when and how to conduct board evaluation. Arguments on one side over structure or procedure focused on how to strengthen board independence to induce challenge, expanding the board's ability to exercise its "control" function. The arguments on the other focused on how these measures would prove divisive, pitting directors against each other and splitting the board between executive and non-executive members.

Contributors in each time period evoked a theme concerning the nature of accountability. On one side we hear voices emphasizing the need for boardroom challenge, which would constrain managerial discretion; on the other - and particularly though not exclusively from corporate actors - come those seeking collegiality and contributions to strategy. Taken together they concern the ethos of the boardroom. 


\section{Boardroom ethos}

How directors behave - that is, behaviour within boards and between boards and shareholders - has been an important concern of the code since its inception, but one where the codes' authors have accepted that a code could have little direct impact. As a result, the code has sought to deal with behavioural issues by proxy. Structures and procedures seek to limit the discretion of board and, thus, the range of possible behaviour. Independence of mind aims to encourage constructive boardroom challenge; lacking a mechanism to ensure it, the code settles for definitions of independence. Some provisions, including controversial ones like board evaluation, may prescribe activities of the board in the hope they will lead to changes in behaviour. With the financial crisis of 2007-09, however, came stronger acknowledgement that these proxy approaches were insufficient.

Board ethos in the Cadbury debate. Documents in the Cadbury Archive show the committee's concern the code might miss the target. A hint comes from the chairman's document (CAD-01265; NB: references with the prefix CAD- refer to the document number in the Cadbury Archive at the University of Cambridge) prepared for the committee as it reviewed all the responses to its May 1992 draft report on September, when the committee would agree the thrust and some detail for final report. A note in an appendix called "Table of Points for Discussion" includes item 12 on "The Board", where the note-writer, in what appears to be Sir Adrian's handwriting, writes: "More emphasis on behaviour needed, less on structure?"

That question does not appear in document offered for the committee's deliberations, but several of the changes agreed that day came in response to concerns about excessive prescription and the "tone" of the draft report, matters that link structure and behaviour. This debate suggests recognition by the committee of the tension between structure and agency in achieving board 
effectiveness. In his submission to the committee, Richard Lloyd, the Vickers chairman, put it this way:

... your Report perhaps should pay more heed in your final version to certain behavioural aspects which are, in our view, central to a Board's

effectiveness.... most U.K. Boards, anyway those of medium-size companies, are probably more intimately involved in the knowledge, understanding and direction of the business than is the case with counterparts across the Atlantic (CAD-01357).

These "behavioural aspects" echo the need for the "presence" and "use" of knowledge and skills in the Forbes and Milliken (1999) model of board effectiveness. Lloyd links them to the "genuinely unitary" nature of UK boards, as opposed to the more supervisory approach in the US. Paul Girolami, Glaxo's chairman, worried that the draft cast non-executives as "watchdogs or guardians" of interests of shareholder or even "the public":

We do not see this as the only - or even primary — role of the non-executive directors. They bring to the boardroom independence and outside experience which cannot be provided by the executive directors, and those qualities are (or ought to be) deployed to enhance the general decision-making of the Board on all the aspects of corporate affairs with which it has to deal. The constructive harnessing of this spectrum of experience requires the creation of a team ethos (CAD-02105).

The equine metaphor of "constructive harnessing", coupled with the electromagnetic and colourful metaphor in "spectrum", invokes images the sense of abundant and unruly force channelled to good purpose. Use of "team ethos" is valorized as a "creation".

The self-described "professional chairman" J.B.H. Jackson put "a lot of effort into keeping boards united and am nervous of external interventions which could run against this"; he was "particularly nervous of cultivating the notion that the standards of behaviour anticipated by 'the City' differ between executive and non-executive directors" (CAD-02143). Here "the City" - the financiers in the City of London - is a distant, alien force seeking to divide those "united" on the board. 
Stanley Kalms, chairman of Dixons, wrote about the "unique cultures" of companies as justifying the assertion that there was "little benefit in absolute uniformity for its own sake" and warning against a code that "did not recognise individuality" (CAD-02167). Sir Richard Greenbury, chairman of Marks \& Spencer, said companies "must act as a cohesive unit"; the context makes clear this refers in particular to boards. Moreover, "whatever Code or Regulation may be in place, the issue [of boardroom power] will be decided by the mix of personalities" (CAD-02343).

These comments emphasize simultaneously the singularity of companies and the unity boards. They perceive a threat in a one-size-fits-all code; the individuality of personalities within the boardroom contributes to the unity of the unitary board. The purpose this unity-inindividuality served was expressed by the Confederation of British Industry in arguing that the draft

... understates the contribution which the non-executives can make to the growth of a business: their different experience brings a fresh eye to problems and the development of strategy (CAD-02349).

Non-executives contribute scarce resources ("experience", "a fresh eye") for the sake of developing strategy and promoting growth. These views paint a picture in which the board is an exciting place to be, a place where structures enable more than they constrain, a place alive with contradictions and uncertainties, and a place the draft code threatened to disrupt.

Such considerations are largely absent from submissions by investors, their advisors and accountancy firms. One of the few investors that remarked on it was Legal \& General. It welcomed the draft's formal definition of differing roles for executives and non-executives but put emphasis not on the control function of non-executives but their service: "balance is provided between executive responsibility for day to day management and non-executive strategic input" (CAD-02353). The investment company 3i went further, noting that it was 
worried the draft wanted non-executives to act as "corporate policeman" when they were needed to contribute to policy development. It installed directors on the companies in which it invested "to benefit the business not to police our investment" (CAD-02387). It is worth noting that L\&G and $3 \mathrm{i}$ were themselves major listed companies as well as important investors.

Board ethos in the post-Higgs debate. The Higgs Review of the effectiveness of nonexecutive directors sought to emphasize the importance of behaviour for the effectiveness of boards. In the body of his report, Higgs added: "The key to non-executive director effectiveness lies as much in behaviours and relationships as in structures and processes" (2003, Paragraph 6.3), before outlining the "behaviours and personal attributes" of non-executives (Paragraphs 6.9-6.19). He also provided guidance on the behaviour of effective chairmen in an annex. $\mathrm{He}$ used "behaviour" and "behaviours" almost interchangeably, leaving readers to interpret to what extent they mean the general depiction of the interaction of directors or observable phenomena. Respondents, particularly but not exclusively from corporations, worried that proposed prescriptions would require specific behaviours, leading to divisions within unitary board and harming performance, rather than fostering trust. We look next at a specific case of their impact: the role of the senior independent director, or SID, and how it would divide the board.

Higgs recommended the SID have a direct relationship with investors. Other non-executive directors meet investors, too, but they should "rely on the chairman and the senior independent director to ensure a balanced view is taken" (Higgs, 2003, Paragraph 15.16). The SID, by contrast, "should attend sufficient of the regular meetings of management with a range of major shareholders to develop a balanced understanding of the themes, issues and concerns of shareholders" (2003, Paragraph 15.15). Moreover, Higgs proposed the SID be available to shareholders "if they have reason for concern that contact through the normal channels of 
chairman or chief executive has failed to resolve" (2003, Paragraph 7.5). To many respondents, and especially company chairmen, this challenged the authority of the chairman. The CBI responded in these terms:

Business is concerned that the proposed Code inadvertently undermines the role of the chairman of a company. It is in no one's interests that this happens (CBI, 16 April 2003, Paragraph 10).

We are also very concerned about the proposed role of the senior independent director. Business believes that this could inadvertently create three separate forces in a board whereas boards need to be a united force. The Cadbury Report identified the danger of a CEO dominating the board. What the Report says on the senior independent director actually does increase the potential risk of a CEO playing off the senior independent against the chairman and thereby weakening the chairman. This very much undermines the Cadbury philosophy (CBI, 16 April 2003, Paragraph 12).

Here the trade association seeks to assert authority by identifying its view with that of "Business", claiming through a totum pro parte authority beyond the scope of its (already powerful) membership. That the "undermining" is "inadvertent" seeks to prevent damage without provoking retaliation. By suggesting Higgs might undermine the aims of Cadbury and thus strengthen the hand of the chief executive, the CBI attacks Higgs by invoking the very logic of his review.

Baroness Hogg, chairman of the listed private equity group $3 \mathrm{i}$ and one very few women respondents, said Higgs did "not sufficiently distinguish between the 'backstop' role of the Senior Independent Director, and the day-to-day responsibilities of the Chairman" (02 April 2003). This is language that defends ("backstop") and thus maintains the status quo and her own role, while seeking to disrupt the changes Higgs planned. Lord Weir, chairman of the construction group Balfour Beatty, argued that the "promotion" of the SID would "undermine the role of the Chairman". His company had not seen the need to follow Cadbury's guidance on designated a senior non-executive in view of the independence of the chairman. Martin Broughton, chairman 
of BAT, said investors "rarely avail themselves" of the existing opportunity for contact with other directors. Moreover, he called another of the Higgs recommendations - that the chairman not chair the nominations committee or even sit on the audit and remuneration committees “constitutionally unsound”.

These and other expressions of concern from the corporate side might be seen as chairmen protecting their own positions. But their reasoning invokes corporate benefit arising from trust and collegial behaviour. Moreover, similar sentiments appear in submissions from mainstream investors and their representatives, though in less forceful language. It was a shared issue, if perhaps with different salience to these two core groups.

Board ethos in the post-financial crisis debate. As the debate got underway in 2009 , the Association of British Insurers called attention to relatively new terminology in the field: behavioural governance. The ABI's first submission urged the code-writers to recognize that how people relate is more important than compliance. It did so by drawing a distinction between substance and form:

In our view the Code, which represents form, can only be effective if the subjects (in most cases the non-executives) apply its principles properly, thereby creating the substance. This application may be termed behavioural governance. Behavioural governance will be affected by such attributes as skills and experience of the individuals, but the two most important attributes a non-executive must have is personal integrity and good judgement. The ABI recognises that it is highly difficult to demonstrate such attributes through a Code, we therefore believe that the most effective way to assess this is through interaction and dialogue between non-executives and investors (ABI, May 2009, pp. 2-3).

The value descriptors here are "integrity" and "judgement" not compliance. The mechanisms are "interaction" and "dialogue", though crucially these terms refer to the relationship between directors and investors, placing emphasis on hierarchical accountability rather than mutuality and 
trust in the boardroom. It acknowledges shareholder primacy while also seeking to move directors' actions away from narrow compliance.

The ABI's submission returned to the theme two pages later when discussing risk management:

The ability to understand the risks includes an element of judgement. This therefore is an aspect of behavioural governance that investors, as outsiders, will always to a degree struggle to fully grasp. One method of addressing this is to look to "expert" directors to provide comfort. However, whilst we support the concept of a financial expert on an Audit Committee and relevant expertise being present on the board, we would counsel against over reliance on "experts". It is our experience that whilst experts are useful they also have a tendency to be more easily "captured" as they will naturally see things in a similar manner to other experts, usually management. As important as expert knowledge is, it must be coupled with keen skills of critical analysis, the ability to constructively challenge and question assumptions. Also, other directors may tend to rely too much on the views of the 'expert' rather than bringing their own judgement to bear (ABI, May 2009, p. 5, punctuation inconsistencies in the original).

The section is worth quoting at length because, unlike other submissions from central actors or its own submissions on other points, the ABI here elaborated its argument, rather than relying upon assumed meanings. Much of the debate preceding the consultation concerned how independent non-executives on bank boards had failed to understand risk. One solution, suggested in the Walker Review two months later, was greater expertise. But here the ABI, a trade association for risk experts, argued against expertise, and in rather forceful terms. Experts were "more easily 'captured"“, so other directors must bring "judgement to bear". The experts themselves must be more than expert; they must also have "keen skills of critical analysis", and then "constructively challenge" and "question assumptions". This argument maintains the institution of the code with its emphasis on independence even as it seeks to push it along the path of relying more on behaviour. That the language here is much more vivid than in much of the rest of its submission suggests that its author(s) saw this as a crucial issue. The institutional 
work is moving in two directions, disrupting the code's reliance on structure and independence while maintaining them as well.

Other submissions also placed emphasis on behaviour more than compliance. The CBI's first submission spoke of the importance of the more general importance of having a "culture of challenge" in the boardroom, arising from having a "broad talent pool" of non-executive directors, before adding:

The effective application of the Code's principles is largely reliant on the behavior [sic] of individuals and their interactions. This is not something that can sensibly be legislated for or regulated (CBI, May 2009, p. 2).

In contrast to the ABI submission, this account of behaviour and these interactions are internal to the board, not also in relation to shareholders. Moreover, neither the code-writers nor government can "sensibly" contribute much to improve it. The CBI's language affirms the code's value while undermining readings of it the emphasize structure. It denigrates legislation and regulation, implicitly also denigrating the more regulatory approaches to the code implicit in the compliance mentality other contributors, particularly peripheral actors, had stressed.

The submission from GC100, an association of corporate counsel from the largest companies, made a similar point in suggesting a non-regulatory approach:

The Code will only provide a framework for good governance but will not alleviate the issues caused by bad management within a company. These behavioural issues can certainly be influenced through a robust board/committee evaluation process and possibly through guidance on best practice from the FRC (GC100, May 2009, p. 4).

This view affirms the value of the code even as it challenges it: the code is "only" a framework, though the committees it has legitimated can influence behaviour through "robust" process of evaluation, thus affirming while simultaneously questioning the effectiveness of code. SABMiller identified with the CG100 stance in its submission, before adding: 
If there were governance weaknesses that contributed to the current crisis, it was in the application of the Code rather than a lack of prescription within the Code itself. Adding extra governance requirements is likely to lead to more box ticking and hamper effective scrutiny by non executive directors by occupying time with form rather than looking at substance. Key to the effectiveness of corporate governance is the calibre of the individuals involved, and that they have a clear understanding of their role and responsibilities and the tools necessary to discharge their responsibilities effectively (SABMiller, May 2009, p. 1).

The contrast between "form" and "substance" returns, as do the limitations of codes in dealing with behaviour. Articulation of code creates "more box ticking", one of many uses of the derogatory phrase made in submissions from actors in central positions. Emphasis is placed instead on the "calibre of the individuals" with the "necessary" tools. That could be read as a request for more tools, had not the passage already warned that extra requirements would "hamper effective scrutiny" and thus be counterproductive. This is language aimed at maintaining the code, and the logic of corporate governance as SABMiller interprets it, but also to disrupt the plans of others to assert their interpretation of codes as defining acceptable behaviour, not merely providing structures within which agents can act.

As the three consultations progressed, the topic returns from a large number of actors. The CBI's October 2009 submission suggested: "Promoting a culture of respect, trust and challenge is the most important issue, and ultimately the job of the chairman. The CBI believes that there is only so far you can codify all of this" (p. 3). A few pages later in discussing board evaluation, it added:

The key aspect of board performance is behavioural, and therefore much less amenable to formal "testing". External evaluation should not be a substitute for open debate and robust challenge between the Executive and the NEDs, nor effective communication and engagement with shareholders (CBI, October 2009, p. 6). 
Not all respondents agreed. The second submission by Fair Pensions, an advisory firm to pension funds, responded to the FRC assertion that "There is a recognition that the quality of corporate governance ultimately depends on behaviour not process" in the following terms:

Everyone accepts that good governance depends on behaviour and that regulation alone is not enough. The practical question, however, is what form of regulation will best promote the required behaviour (Fair Pensions, October 2009, p. 2).

The word "however" does the rhetorical change of direction and one that invokes a different, regulatory logic of behaviour more akin to agency than stewardship theory in corporate governance, emphasizing more the structure in an institutional approach to the field than the concept of embedded agency. This form of institutional work is both maintaining the code and disrupting attempts of those in more central positions to maintain their understandings of the code.

Voices present but missing from this debate. As an advisory firm on ethical investments, Fair Pensions sits some distance from the centre of the investment field. Theirs were among the few documents from more peripheral actors to make any significant statements about behaviour, and its contribution emphasizes the primacy of control through regulation, not cohesiveness, collegiality and trust. Other non-core actors - whether close intermediates like accountancy firms or lawyers, or more distant ones like academics or proxy voting agencies - also focused on structure and independence, that is, on achieving greater control, not the contribution of enhanced service. Perhaps they were too removed from what goes on inside the "black box" of the boardroom (Huse, 2005; Zona \& Zattoni, 2007) to feel competent to judge how codes might affect behaviour. 


\section{Discussion}

This paper provides several insights concerning corporate governance, the nature of institutional work, and the process of identification. With the exceptions of corporate responses the contributions to the debates were largely done by organizations. But occasionally named individuals filed the statements, and among the organizational submissions, the corporate governance specialists at many were individuals well known in the field with strong reputations they developed in part through their continuing involvement in the process of codification.

\section{Institutional work in corporate governance}

Writing the code was in general a conservative process throughout the period. Despite crises of legitimacy, these efforts arose largely outside political and legislative purview. As a consequence, the actors engaged in them were largely those with vested interests in incumbent practices as much as future outcomes. Those conditions suggest processes where little institutional change would emerge and the work done would be mainly of the "maintaining" varieties in Lawrence and Suddaby (2006).

Work in 1992. Cadbury's work was institutional entrepreneurship (DiMaggio, 1988), seizing an opportunity when legitimacy of established practices had come into question. The process, including the consultations and the informal meetings, research and media coverage that surrounded it, provided repeated opportunities for the work Lawrence and Suddaby (2006) call educating, theorizing, defining and vesting. The consultation worked by constructing normative networks among contributors and between them and the drafting committees and individuals. The initial work changed normative associations by connecting intended practices with moral underpinnings, which were reinforced by the association of the Cadbury family over generations 
with practices we now call social responsibility. Cadbury was the moral face of capitalism; Maxwell was the opposite.

Enlisting important industrialists for the committee and soliciting views from others brought potential opponents into a position where they needed to articulate their position from within the frame Cadbury's draft had set. In contributing to the debate, opponents construct identities not too far removed from terms the draft had given; its new mechanisms then facilitate diffusion of the new practices, or at least their translation (Czarniawska \& Joerges, 1996) by actors less than thoroughly convinced by the arguments they have heard. This echoes the projective agency in the version of institutional work in Battilana and D'Aunno (2009). But holding open competing views through the comply-or-explain regime, the code that emerged allows actors in the field to keep multiple identities following different logics in a kind of suspended animation as they incorporate the code in their own practice. This identity work (Creed et al., 2010; Lok, 2010) suggests a need to add another type of practical-evaluation agency to Battilana and D'Aunno's phase of creating institutions.

Work in later versions. Subsequent major versions paint a more complex picture. With a formal code in place, the canvas that Higgs and then the FRC used in 2003 was not blank. Existing practices from Cadbury had been institutionalized over a decade and mythologized, a form of "maintaining" work (Lawrence \& Suddaby, 2006). Through the iconic status of the code around the world, those practices had won over critics from 1992. Contributions to the "fatal flaws only" review in 2003 suggest that many had come to identify with Cadbury precepts, including ones they had viewed as radical in 1992. That is, these organizations and in some cases individuals had learned to adapt through translation and bricolage to use the code and still suit their companies' circumstances. 
They praised the Higgs Review (2003) and its insights into non-executive directors, a form of "valorizing", but disputed its recommendations, "demonizing" as alien in their attempt to split the board. This is work by these actors that Lawrence and Suddaby would call "maintaining" incumbent arrangements but it is also disrupting the entrepreneurship in Higgs. Nicholson faced that fury with a fudge. He converted Higgs's recommendation of a definition of independence involving a six-year tenure into what came to be called the "nine-year rule" created in the 2003 Combined Code. That was work that Battilana and D'Aunno (2009) would call "repairing" or a change Lawrence and Suddaby (2006) would see as "enabling" - both of the "maintaining" variety - but maintaining entrepreneurial ideas, while disrupting existing arrangements.

In 2010, Sir Christopher Hogg's changes to the code recognized issues left untreated in the Cadbury and Higgs inquiries, that the boardroom ethos was more important than structures or formal definitions of independence. Contributions to that consultation nonetheless brought up old ideas and issues up for reconsideration, ideas that sought again to address questions of structure and definitions of independence. The institutional work was a repeat of prior attempts by some to repair and others to undermine the moral associations of a code that had failed to prevent a recurrent wave of governance failings. What emerged, however, was advocacy of translation and bricolage, advocacy of deinstitutionalization through explanations rather than compliance. The 2010 code picked up and amplified the subtext of the discourse that spoke of the limitations of code and the need for a combination of trust and challenge, respect within critique, that corporate actors and some others had advocated since the earliest days, but which previous authors of the code had reflected only in part. Was this work disrupting existing arrangements, maintaining the spirit by repairing the language, or creating something rather different? 
Actors from different parts of the broader field of corporate governance would view these examples of work differently. Those that start with a logic of control as the purpose of boards could find the advocacy from corporations and the actions of the author in the 2010 process as disrupting to the central purpose corporate governance. Those that start from a logic of service, of the board as a solution to resource constraints, could see in the 2010 process invention and advocacy of a new set of arrangements that simultaneously undermined incumbent ones.

Work as contingent on position in field. This discussion suggests the concept of institutional work is contingent on the position of the actors in the broader field: work one actor might view as maintaining an institution is one that disrupts diffusion of arrangements that others advocate, a somewhat different view from that developed by Creed and colleagues (2010). In their case, marginal actors committed to the institutions acted as change agents, thus simultaneously maintaining and disrupting it. Here, actors hold differing interpretations of the key tenets of institution - what constitutes board effectiveness - and its logic - control or service - each supported by texts and discourses that permit adherents to hold them in contradiction. This is true particularly for this case, because the field is unsettled.

\section{Codification and identity}

This paper demonstrates processes of institutional work creating the code and then helping it to evolve it over time. The initial hostility to provisions in Cadbury seen as disrupting the ethos of UK boards was diminished and in some cases no longer present later on. That is, the institutionalization of the code has taken hold as individuals and organizational actors adapted their practices, and found ways to sustain the elements of ethos of boards. When the subsequent revision after the Higgs Review challenged their understandings of board ethos, those voices argued for Cadbury but against its extension into a more confrontational board, but then lost the 
argument. By 2010, however, the process of codification reopens the debate about ethos and, without rolling back the provisions installed through Higgs, urges greater use of explanation rather than compliance, acknowledging the fears that corporate governance had become oppressive to the way boards work.

Through the process of codification, that is through the institutional work of creating, maintaining and occasionally seeking to disrupt the code, contributors' view moderate. Actors from the investment side voice ideas identified with corporate economic interests. Similarly, corporate actors come to voice sentiments that acknowledge investor interests. Some non-core actors' views also converge, as they identify through the processes of codification and institutional work with an emerging logic of corporate governance itself. This reflects what individuals active in the UK corporate governance field have remarked anecdotally that individuals identify as corporate governance specialists, sometimes more strongly than with the organization and field (corporations, investor, advisor, agitator) in which they work.

\section{Conclusions}

There are unanswered questions, two of which warrant brief attention here. First are the absent voices. The consistency of the respondents masks changes that have taken place of the first two decades of the code's existence. The 2010 consultation process went largely without comment from hedge funds, sovereign wealth funds and other foreign investors, suggesting that its legitimacy may over time come into question. Second, the respondents are individuals, often writing in a corporate persona. If the finding of this study is that actors show greater allegiance to the principles of the code than one might expect from their organizations, the legitimacy may erode as individuals depart from the scene or structural changes occur in the investment supply chain. Perhaps corporate governance has a biography, as well as a history. 
The discussion boardroom ethos has roots in the experience of individuals, and not just corporate actors, responding to the issues the consultations raised. As we have seen, respondents came from a variety parts of the investment supply chain, bringing with them both a range of views roughly corresponding to their economic interests and a large degree of shared values about the nature of corporate governance and the importance of finding better ways of making it work. The contributions suggest that corporate governance means more to the individuals than their narrow self-interest of their organizations would dictate. In that sense they have developed identities that embrace the broader field of corporate governance, not just the organizational field in which they sit.

The study also leads us to think anew about the processes of institutionalization. The early puzzle that confronted institutional scholars was to explain why organizations were so often the same, and why that sameness persisted despite evolving market conditions and product and process innovation (Meyer \& Rowan, 1977). The effort to institutionalize the work of boards of directors, to reach a consensus of how directors should interact and what ethos boardrooms should thus have, is to deny the individuality of firms and their strategic imperative to be different from each other.

It may be that boards are already abstracted from the day-to-day business of managing firmspecific resources and activities. If so then codifying their practices could be an appropriate general principle, and one that might apply despite the varying formal institutions of law and regulations that the varieties of capitalism approach depicts (Hall \& Soskice, 2001). If so, then codes might need to be more, not less flexible if they are to function under varying types of organizations and types of market conditions, as well as varying formal institutional arrangements. That seems to be what the comply-or-explain provision of the UK code is trying to 
do. That seems to argue for the notion of greater board discretion we observe in the attempts by practitioners to shape the recommendations of what the code says about how directors interact even as those actors identify with governance as a vocation and reach a growing consensus about the nature of the task.

\section{References}

Aguilera, R. V. (2005). Corporate Governance and Director Accountability: an Institutional Comparative Perspective. British Journal of Management, 16(S1), S39-S53.

Aguilera, R. V., \& Cuervo-Cazurra, A. (2004). Codes of Good Governance Worldwide: What is the Trigger? Organization Studies, 25(3), 415-443. doi: 10.1177/0170840604040669

Aguilera, R. V., \& Cuervo-Cazurra, A. (2009). Codes of Good Governance. Corporate Governance: An International Review, 17(3), 376-387.

Alvesson, M., \& Kärreman, D. (2000). Varieties of Discourse: On the Study of Organizations through Discourse Analysis. Human Relations, 53(9), 1125-1149. doi: $10.1177 / 0018726700539002$

Barroso, C., Villegas, M. M., \& Pérez-Calero, L. (2011). Board Influence on a Firm's Internationalization. Corporate Governance: An International Review, 19(4), 351-367. doi: 10.1111/j.1467-8683.2011.00859.x

Battilana, J., \& D'Aunno, T. (2009). Institutional work and the paradox of embedded agency. In T. B. Lawrence, R. Suddaby \& B. Leca (Eds.), Institutional Work: Actors and Agency in Institutional Studies of Organizations (pp. 31-58). Cambridge: Cambridge University Press.

Bévort, F., \& Suddaby, R. (2016). Scripting professional identities: how individuals make sense of contradictory institutional logics. Journal of Professions and Organization, 3(1), 17-38. doi: 10.1093/jpo/jov007

Cadbury Archive. (2010). The Cadbury Archive. Judge Business School, Cambridge University. Retrieved June 13, 2011, from http://www.jbs.cam.ac.uk/cadbury/index.html

Chia, R. (2000). Discourse Analysis as Organizational Analysis. Organization, 7(3), 513-518. doi: $10.1177 / 135050840073009$

Clegg, S. R. (2010). The State, Power, and Agency: Missing in Action in Institutional Theory? Journal of Management Inquiry, 19(1), 4-13. doi: 10.1177/1056492609347562

Creed, W. E. D., Dejordy, R., \& Lok, J. (2010). Being the Change: Resolving Institutional Contradiction through Identity Work. Academy of Management Journal, 53(6), 1336-1364. 
Czarniawska, B. (2007). Has Organization Theory a Tomorrow? Organization Studies, 28(1), 27-29. doi: 10.1177/0170840607073565

Czarniawska, B., \& Joerges, B. (1996). The travel of ideas. In B. Czarniawska \& G. Sevon (Eds.), Translating Organizational Change (pp. 13-48). Berlin: de Gruyter.

DiMaggio, P. J. (1988). Interest and agency in institutional theory. In L. G. Zucker (Ed.), Institutional patterns and culture (pp. 3-32). Cambridge, MA: Ballinger.

DiMaggio, P. J., \& Powell, W. W. (1983). The Iron Cage Revisited: Institutional Isomorphism and Collective Rationality in Organizational Fields. American Sociological Review, 48(2), 147-160.

Emirbayer, M., \& Mische, A. (1998). What Is Agency? The American Journal of Sociology, 103(4), 962-1023.

Forbes, D. P., \& Milliken, F. J. (1999). Cognition and corporate governance: Understanding boards of directors as strategic decision-making groups. Academy of Management Review, 24(3), 489-505. doi: 10.5465/AMR.1999.2202133

FRC. (2004, February 10). 2003 Annual Review. UK Financial Reporting Council. Retrieved September 2, 2011, from http://www.frc.org.uk/documents/pagemanager/frc/annualreview2003.pdf

FRC. (2010). The UK Corporate Governance Code. UK Financial Reporting Council. Retrieved May 29, 2010, from http://www.frc.org.uk/documents/pagemanager/Corporate_Governance/UK\%20Corp\%20Go v\%20Code\%20June\%202010.pdf

Greenwood, R., \& Hinings, C. R. (1996). Understanding Radical Organizational Change: Bringing Together the Old and the New Institutionalism. Academy of Management Review, 21(4), 1022-1054. doi: 10.5465/AMR.1996.9704071862

Greenwood, R., \& Suddaby, R. (2006). Institutional entrepreneurship in mature fields: The Big Five accounting firms. Academy of Management Journal, 49(1), 27-48.

Greenwood, R., Suddaby, R., \& Hinings, C. R. (2002). Theorizing change: The role of professional associations in the transformation of institutionalized fields. Academy of Management Journal, 45(1), 58-80.

Hall, P. A., \& Soskice, D. (Eds.). (2001). Varieties of Capitalism: The Institutional Foundations of Comparative Advantage. Oxford: Oxford University Press.

Higgs, D. (2003). Review of the Role and Effectiveness of Non-Executive Directors. Retrieved October 15, 2006, from http://www.ecgi.org/codes/documents/higgsreport.pdf

Holm, P. (1995). The Dynamics of Institutionalization: Transformation Processes in Norwegian Fisheries. Administrative Science Quarterly, 40(3), 398-422. 
Huse, M. (2005). Accountability and Creating Accountability: a Framework for Exploring Behavioural Perspectives of Corporate Governance. British Journal of Management, 16(s1), S65-S79.

IFC. (2005). The Irresistible Case for Corporate Governance. International Finance Corp. Retrieved April 26, 2009, from http://ifcln1.ifc.org/ifcext/corporategovernance.nsf/AttachmentsByTitle/The_Irrisistible_Case _Text/\$FILE/IrresistibleCase4CG.pdf

IFC. (2007). Corporate Governance Manual: Belgrade. Retrieved March 3, 2009, from http://www.ifc.org/ifcext/cgf.nsf/AttachmentsByTitle/CorporateGovernance_manual_Belgra de2007/\$FILE/Corporate_Governance_Manual_New.pdf

Kim, B., Burns, M. L., \& Prescott, J. E. (2009). The Strategic Role of the Board: The Impact of Board Structure on Top Management Team Strategic Action Capability. Corporate Governance: An International Review, 17(6), 728-743.

Kraatz, M. S. (2011). Two Cheers for Institutional Work. Journal of Management Inquiry, 20(1), 59-61. doi: 10.1177/1056492610387223

Lawrence, T. B., Hardy, C., \& Phillips, N. (2002). Institutional effects of interorganizational collaboration: The emergence of proto-institutions. Academy of Management Journal, 45(1), 281-290.

Lawrence, T. B., \& Suddaby, R. (2006). Institutions and Institutional Work. In S. Clegg, C. Hardy, T. B. Lawrence \& W. R. Nord (Eds.), The Sage handbook of organization studies (2nd ed., pp. 215-254). London: Sage.

Lawrence, T. B., Suddaby, R., \& Leca, B. (2011). Institutional work: Refocusing institutional studies of organization. Journal of Management Inquiry, 20(1), 52-58. doi:

$10.1177 / 1056492610387222$

Lok, J. (2010). Institutional Logics as Identity Projects. Academy of Management Journal, 53(6), 1305-1335. doi: 10.5465/AMJ.2010.57317866

Love, I. (2011). Corporate Governance and Performance around the World: What We Know and What We Don't. The World Bank Research Observer, 26(1), 42-70. doi: 10.1093/wbro/lkp030

Marnet, O. (2007). History repeats itself: The failure of rational choice models in corporate governance. Critical Perspectives on Accounting, 18(2), 191-210. doi: 10.1016/j.cpa.2005.11.010

McNulty, T., Roberts, J., \& Stiles, P. (2003, January 13). Creating accountability within the board: The work of the effective non-executive director. A report for the Review of the Role and Effectiveness of the Non-Executive Director conducted by Mr Derek Higgs. Retrieved August 21, 2010, from 
http://webarchive.nationalarchives.gov.uk/tna/+/http://www.dti.gov.uk/cld/non_exec_review/ pdfs/stilesreport.pdf/

Meyer, J. W., \& Rowan, B. (1977). Institutionalized Organizations: Formal Structure as Myth and Ceremony. American Journal of Sociology, 83(2), 340-363.

Mitchell, R. K., Agle, B. R., \& Wood, D. J. (1997). Toward a theory of stakeholder identification and salience: Defining the principle of who and what really counts. Academy of Management Review, 22(4), 853-886.

MORI. (2002). Non-Executive Directors Survey - The Higgs Review Topline Results. Retrieved September 2, 2011, from http://www.ipsosmori.com/Assets/Docs/Archive/Polls/dti-higgs.pdf

Nicholson, B. (2008). The role of the regulator. In K. Rushton (Ed.), The Business Case for Corporate Governance (pp. 100-118). Cambridge: Cambridge University Press.

Nordberg, D., \& McNulty, T. (2013). Creating better boards through codification: Possibilities and limitations in UK corporate governance, 1992-2010. Business History, 55(3), 348-374. doi: 10.1080/00076791.2012.712964

O'Rourke, D. (2003). Outsourcing Regulation: Analyzing Nongovernmental Systems of Labor Standards and Monitoring. Policy Studies Journal, 31(1), 1-29.

OECD. (1999). OECD Principles of Corporate Governance. Organisation for Economic Cooperation \& Development. Retrieved January 8, 2008, from http://www.ecgi.org/codes/documents/principles_en.pdf

OECD. (2004). OECD Principles of Corporate Governance, Revised. Organisation for Economic Co-operation \& Development. Retrieved October 15, 2006, from http://www.oecd.org/dataoecd/32/18/31557724.pdf

Oliver, C. (1992). The Antecedents of Deinstitutionalization. Organization Studies, 13(4), 563.

Paine, L., Deshpandé, R., Margolis, J. D., \& Bettcher, K. E. (2005). Up to Code. Harvard Business Review, 83(12), 122-133.

Rao, H., \& Giorgi, S. (2006). Code Breaking: How Entrepreneurs Exploit Cultural Logics to Generate Institutional Change. Research in Organizational Behavior, 27, 269-304. doi: 10.1016/S0191-3085(06)27007-2

Roberts, J., McNulty, T., \& Stiles, P. (2005). Beyond Agency Conceptions of the Work of the Non-Executive Director: Creating Accountability in the Boardroom. British Journal of Management, 16(S1), S5-S26.

Seidl, D. (2007). Standard Setting and Following in Corporate Governance: An ObservationTheoretical Study of the Effectiveness of Governance Codes. Organization, 14(5), 705-727. doi: $10.1177 / 1350508407080316$ 
Seo, M.-G., \& Creed, W. E. D. (2002). Institutional contradictions, praxis, and institutional change: A dialectical perspective. Academy of Management Review, 27(2), 222-247.

Smith, R. (2003). Audit Committees Combined Code Guidance. Retrieved December 29, 2008, from http://www.ecgi.org/codes/documents/ac_report.pdf

Strauss, A. (1987). Qualitative Analysis for Social Scientists. Cambridge: Cambridge University Press.

Strauss, A., \& Corbin, J. (1998). Basics of Qualitative Research: Techniques and Procedures for Developing Grounded Theory (2nd ed.). London: Sage.

Tyson, L. (2003). The Tyson Report on the Recruitment and Development of Non-Executive Directors, a report to the UK Department of Trade and Industry. Retrieved April 8, 2007, from http://facultyresearch.london.edu/docs/TysonReport.pdf

van Ees, H., Gabrielsson, J., \& Huse, M. (2009). Toward a Behavioral Theory of Boards and Corporate Governance. Corporate Governance: An International Review, 17(3), 307-319.

Vandewaerde, M., Voordeckers, W., Lambrechts, F., \& Bammens, Y. (2011). Board Team Leadership Revisited: A Conceptual Model of Shared Leadership in the Boardroom. Journal of Business Ethics, 104(3), 403-420. doi: 10.1007/s10551-011-0918-6

Walker, D. (2009a, July 16). A review of corporate governance in UK banks and other financial industry entities. HM Treasury Independent Reviews. Retrieved July 16, 2009, from http://www.hm-treasury.gov.uk/d/walker_review_consultation_160709.pdf

Walker, D. (2009b, November 26). A review of corporate governance in UK banks and other financial industry entities: Final recommendations. HM Treasury Independent Reviews. Retrieved November 26, 2009, from http://www.hmtreasury.gov.uk/d/walker_review_consultation_160709.pdf

Zietsma, C., \& McKnight, B. (2009). Building the iron cage: Institutional creation work in the context of competing proto-institutions. In T. B. Lawrence, R. Suddaby \& B. Leca (Eds.), Institutional Work: Actors and Agency in Institutional Studies of Organizations (pp. 143175). Cambridge: Cambridge University Press.

Zona, F., \& Zattoni, A. (2007). Beyond the Black Box of Demography: board processes and task effectiveness within Italian firms. Corporate Governance: An International Review, 15(5), 852-864. doi: 10.1111/j.1467-8683.2007.00606.x 